\title{
Article
}

\section{Local Community Composition Drives Avian Borrelia burgdorferi Infection and Tick Infestation}

\author{
Marie Lilly ${ }^{1, *}$, Wilmer Amaya-Mejia ${ }^{2}$, Lucas Pavan ${ }^{3}$, Ceili Peng ${ }^{4}$, Arielle Crews ${ }^{5}$, Nghia Tran ${ }^{1}$, \\ Ravinder Sehgal ${ }^{1}$ and Andrea Swei ${ }^{1, *(D)}$
}

check for updates

Citation: Lilly, M.; Amaya-Mejia, W.; Pavan, L.; Peng, C.; Crews, A.; Tran, N.; Sehgal, R.; Swei, A. Local Community Composition Drives Avian Borrelia burgdorferi Infection and Tick Infestation. Vet. Sci. 2022, 9,

55. https://doi.org/10.3390/ vetsci9020055

Academic Editors: Ryo Nakao and Mohamed Abdallah

Mohamed Moustafa

Received: 20 September 2021

Accepted: 25 January 2022

Published: 29 January 2022

Publisher's Note: MDPI stays neutral with regard to jurisdictional claims in published maps and institutional affiliations.

Copyright: (C) 2022 by the authors. Licensee MDPI, Basel, Switzerland. This article is an open access article distributed under the terms and conditions of the Creative Commons Attribution (CC BY) license (https:// creativecommons.org/licenses/by/ $4.0 /)$.
1 Department of Biology, San Francisco State University, 1600 Holloway Ave., San Francisco, CA 94132, USA; nghjatran1100@gmail.com (N.T.); sehgal@sfsu.edu (R.S.)

2 Department of Ecology and Evolutionary Biology, University of California, Los Angeles, 612 Charles E. Young Drive East, Los Angeles, CA 90095, USA; amayamejiaws@gmail.com

3 Department of Biology, Stanford University, 371 Jane Stanford Way, Stanford, CA 94305, USA; lucas.i.pavan@gmail.com

4 Department of Biology, Massachusetts Institute of Technology, 31 Ames St., Cambridge, MA 02142, USA; ceilipeng@gmail.com

5 San Mateo County Mosquito and Vector Control District, 1351 Rollins Road, Burlingame, CA 94010, USA; arielle.crews@gmail.com

* Correspondence: marievlilly@gmail.com (M.L.); aswei@sfsu.edu (A.S.)

\begin{abstract}
Globally, zoonotic vector-borne diseases are on the rise and understanding their complex transmission cycles is pertinent to mitigating disease risk. In North America, Lyme disease is the most commonly reported vector-borne disease and is caused by transmission of Borrelia burgdorferi sensu lato (s.l.) from Ixodes spp. ticks to a diverse group of vertebrate hosts. Small mammal reservoir hosts are primarily responsible for maintenance of B. burgdorferi s.l. across the United States. Nevertheless, birds can also be parasitized by ticks and are capable of infection with B. burgdorferi s.l. but their role in B. burgdorferi s.l. transmission dynamics is understudied. Birds could be important in both the maintenance and spread of B. burgdorferi s.l. and ticks because of their high mobility and shared habitat with important mammalian reservoir hosts. This study aims to better understand the role of avian hosts in tick-borne zoonotic disease transmission cycles in the western United States. We surveyed birds, mammals, and ticks at nine sites in northern California for B. burgdorferi s.1. infection and collected data on other metrics of host community composition such as abundance and diversity of birds, small mammals, lizards, predators, and ticks. We found $22.8 \%$ of birds infected with B. burgdorferi s.l. and that the likelihood of avian B. burgdorferi s.l. infection was significantly associated with local host community composition and pathogen prevalence in California. Additionally, we found an average tick burden of 0.22 ticks per bird across all species. Predator and lizard abundances were significant predictors of avian tick infestation. These results indicate that birds are relevant hosts in the local B. burgdorferi s.l. transmission cycle in the western United States and quantifying their role in the spread and maintenance of Lyme disease requires further research.
\end{abstract}

Keywords: disease ecology; community ecology; avian hosts; Lyme disease; Borrelia burgdorferi

\section{Introduction}

Globally, zoonotic vector-borne diseases have emerged over the past several decades and constitute a major public health challenge [1-4]. In the United States, Lyme disease is the most commonly reported vector-borne disease to the Center for Disease Control and Prevention (CDC) and the number of human Lyme disease cases has doubled over the last 16 years, currently estimated to exceed 300,000 cases [5]. Lyme disease is maintained by the transmission of the spirochete bacteria Borrelia burgdorferi sensu stricto (s.s.) between Ixodes spp. ticks and their vertebrate hosts [6-8]. The B. burgdorferi sensu lato species complex consists of 18 related genospecies, some of which are zoonotic and others are not. 
In the United States, B. burgdorferi s.s. and a newly discovered, B. mayonii, are the only genospecies known to cause Lyme disease $[9,10]$ but other genospecies, such as $B$. bissettiae have been associated with human disease $[11,12]$.

In the western United States, the primary vector of Lyme disease is the western black-legged tick, Ixodes pacificus [8], a generalist tick that can feed on over 100 species of mammals, birds, and reptiles [13-15]. Some of these so-called reservoir hosts can become infected with B. burgdorferi s.l., amplify the bacteria, and transmit it to uninfected feeding ticks-thus maintaining B. burgdorferi s.l. in the community [16]. A few key mammalian host species identified as B. burgdorferi s.l. reservoirs in the western United States include the western gray squirrel (Sciurus griseus), dusky-footed woodrat (Neotoma fuscipes), and deer mice (Peromyscus spp.) [14,16-20]. Birds are capable of both sustaining B. burgdorferi s.1. infections and transmitting infection to ticks, but the extent of their role in B. burgdorferi s.l. transmission dynamics is not well understood [21-25]. Birds are important sylvatic reservoirs of B. burgdorferi s.l. in parts of Europe, but few studies in North America have quantified the role of birds as tick hosts and pathogen reservoirs [26-29]. Experimental studies have shown that birds can effectively transmit B. burgdorferi s.l. infection to ticks and have been implicated as important carriers of Ixodes spp. ticks between different geographic regions [22,30,31]. Thus, birds may be important in both maintenance and spread of B. burgdorferi s.l. because of their high mobility and shared habitat with important mammalian reservoir hosts [15,21,22].

Ixodes spp. have three post egg life stages, the larva, nymph, and adult stages. Because Borrelia burgdorferi s.l. is not transovarially (vertically) transmitted from adult tick to larvae, the identity and infection status of the larval bloodmeal is the primary determinant of the infection status of nymphal ticks [32]. The nymphal tick poses the greatest threat to human disease transmission because of its small size and the ease with which it might be overlooked, even after a thorough tick check [33-35]. Thus, B. burgdorferi s.l. infection status of nymphal ticks is commonly used as an entomological metric for B. burgdorferi s.l. disease risk. Birds predominantly host larval and nymphal ticks, but their tick burden and ability to transmit $B$. burgdorferi s.l. to feeding ticks varies greatly by species and geographic region $[24,31,36,37]$.

This study aims to resolve unanswered questions regarding ecological drivers of avian B. burgdorferi s.l. infection prevalence and avian tick burden to better understand the role of avian hosts in tick-borne zoonotic disease transmission cycles. We sought to assess how community composition across trophic scales-from tick vector to small mammal to predator communities-affect avian tick burdens and infection prevalence with $B$. burgdorferi s.l. We also ask if certain avian traits are important for predicting tick burden and the likelihood of $B$. burgdorferi s.l. infection. This study adds to the growing body of knowledge regarding the understudied role of avian hosts in B. burgdorferi s.l. transmission dynamics.

\section{Materials and Methods}

\subsection{Site Selection}

Birds were surveyed on field plots from nine oak woodland habitat sites in northern California that were selected to span a patch size gradient as described by Lawrence et al. (2018) [38] and capture a range of I. pacificus host community diversity and composition. Five sites were located in San Mateo County, CA, USA (Filoli Estates (37.46946, -122.31639), Junipero Serra County Park (37.60792, -121.42417), Water Dog Lake Park (37.50311, -122.29889), Windy Hill Open Space Preserve (37.86514, -122.2801), Pulgas Ridge Preserve (37.474749, -122.285120)); two sites were located in Marin County, CA, USA (China Camp State Park (38.00131, -122.48889), Tiburon Uplands Nature Preserve (37.88931, -121.45083)); one site was located in Contra Costa County, CA, USA (Lafayette Reservoir Nature Area (37.88394, -122.13472)); and one site was located in Sonoma County, CA, USA (Spring Lake Regional Park (38.45225, -122.64833)) (Figure 1). Birds were sampled from April to August of 2019 while the tick, mammalian, and reptilian communities were 
sampled from April to May in 2019 during peak questing activity of I. pacificus larvae and nymphs [8,39].

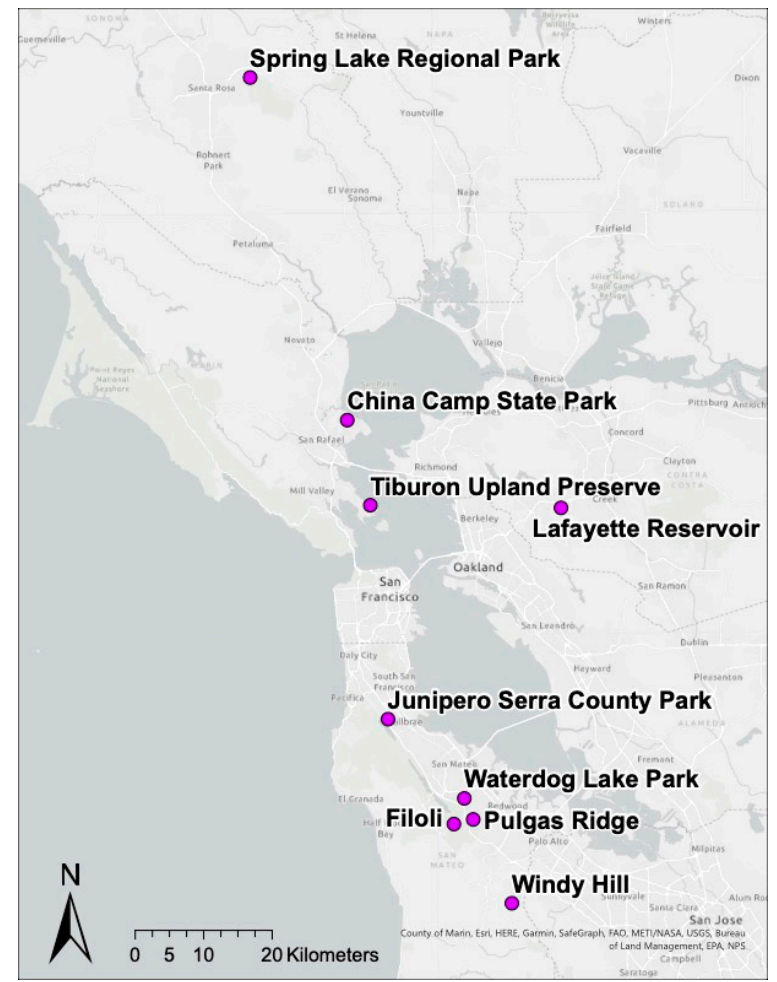

Figure 1. Map of nine sites across Northern California where field plots were established for Lyme disease surveillance and bird, mammalian, tick, and reptilian communities were sampled.

\subsection{Host Surveillance: Birds, Small Mammals, Lizards, and Medium to Large Mammals}

Bird communities were sampled using standard mist-netting techniques (Stanford University IACUC protocol \#33733) [40]. Twelve mist-nets, measuring $12 \mathrm{~m}$ long by $3 \mathrm{~m}$ high, were set up along trails or open spaces in a perpendicular array near the forest edge. Mist netting occurred from 7 am to noon for two consecutive days at each site and were checked at $30 \mathrm{~min}$ intervals. Birds were extracted from the net, identified to species [41,42], banded, sexed, and aged [43]. Morphometrics were recorded for weight, fat score, and bill, tarsus, wing, and tail length. Approximately 5-20 $\mu \mathrm{L}$ of blood for molecular analyses was collected by brachial venipuncture of each captured bird and stored in lysis buffer (10 mM Tris- $\mathrm{HCl} \mathrm{pH}$ 8.0, $100 \mathrm{~mm}$ ethylenediaminetetraacetic acid, 2\% sodium dodecyl sulfate) $[43,44]$. Although B. burgdorferi s.l. is known to colonize mammalian tissue more readily than blood, spirochetes have been found in avian blood analyses, so this standard avian sampling technique was chosen over a more invasive skin biopsy approach [21,45].

Small mammals were trapped at each site on a half-hectare grid using a $7 \times 7$ trapping array (San Francisco State University IACUC protocol \#AU19-01R2). Two Sherman traps were set at each trapping station facing opposite directions from each other with $11.8 \mathrm{~m}$ spacing between each of the 49 sampling stations. Each grid and trapping array were standardized as described by Lawrence et al. (2018) [38] and Salomon et al. (2021) [46]. Small mammals were trapped for three consecutive days at each site. Each animal caught was identified to species in the field and confirmed by molecular analysis of the cytochrome $b$ gene. They were visually sexed, weighed, and uniquely tagged. A $2 \mathrm{~mm}$ circular tissue biopsy was taken from the outer pinna of each ear and immediately stored in $70 \%$ ethanol.

For each site, western fence lizards (Sceloporus occidentalis) were visually surveyed within the 0.5 ha sampling plot along seven evenly spaced transect lines with $11.8 \mathrm{~m}$ between each line. Lizards were sprayed using Idico (Forestry Suppliers, Jackson, MS, USA) tree-marking guns on their dorsum with a diluted latex paint mixture as described by 
Swei et al., 2011 [47]. Lizard surveys took place over three consecutive days with a different paint color used on each day to determine individual lizard's encounter history.

Motion sensor wildlife camera traps (Bushnell models \#119736, \#119836, \#119836C, Bushnell, KS, USA) were set in open spaces and along game trails at each site to capture the relative abundance and movement of predators and other medium to large mammals. Two camera traps were set for a sampling period of 40 days at each site on the same tree facing opposite directions as described by Lawrence et al. (2018) [38]. Animals captured by the camera traps were identified to species by visualizations of the photographs.

Vertebrate species abundance and diversity were calculated at each site. Relative abundance of birds was estimated as the minimum number alive of each species caught in the mist nets at all nine sites [40,48]. Small mammal and western fence lizard abundances were estimated from the mark-recapture trapping data using the R package Rcapture [49]. The relative abundance of predators was calculated by counting the number of unique individuals of each species per photograph per day across the 40-day trapping period [39,46]. Avian, rodent, and predator Shannon diversity were calculated in $\mathrm{R}$ using the vegan package, and richness was calculated as the number of unique species captured [50].

\subsection{Vecotor Surveillance: Bird-Attached and Questing Ticks}

Birds sampled were checked for ticks around the head and all attached ticks were removed and stored in $70 \%$ ethanol for later identification to species and life stage by microscopy using taxonomic keys [51-53].

Questing ticks were collected by standard dragging techniques using a $1 \mathrm{~m}^{2}$ white cotton cloth along seven linear transects within the 0.5 ha sampling plot for a total of $495 \mathrm{~m}^{2}$ sampled at each site [54]. All ticks were stored in 70\% ethanol and identified to species and life stage by microscopy using taxonomic keys [52,53]. Questing I. pacificus nymphal tick abundance was calculated as the total number of I. pacificus nymphal ticks per drag at each site.

\subsection{Pathogen Surveillance: Borrelia burgdorferi Sensu Lato Testing}

DNA was extracted from avian blood samples, small mammal ear tissue biopsies, and questing nymphal ticks for molecular analyses using either Qiagen DNeasy Blood and Tissue Kit (Qiagen, Valencia, CA, USA) or Promega Wizard Genomic DNA Purification Kit (Promega, Madison, WI, USA). Extracted DNA from each sample was screened for B. burgdorferi s.l. with a nested PCR protocol targeting the 5S-23S rRNA intergenic spacer region [55] and then visualized by gel electrophoresis. Positive samples were then identified to genospecies by sequencing (GenBank MZ852103-MZ852212). Four samples did not have enough PCR product for sequencing and were counted as B. burgdorferi s.l. positive based on the strength of the amplicon banding during gel electrophoresis but not identified to genospecies.

\subsection{Statistical Analyses: Probability of Avian Tick Infestation and Borrelia burgdorferi Sensu Lato Infection}

Statistical analyses were performed to assess the avian traits and overall community composition metrics important in driving avian tick burden and the likelihood of B. burgdorferi s.l. infection. Only bird species with a sample size of $\geq 5$ individuals tested and with $\geq 1$ infected individual were included in subsequent analyses. To address what host traits influence avian tick burden, a zero-inflated negative binomial generalized linear mixed-effect model (GLMM) was used to analyze the effect of bird species, sex, mass, foraging substrate, nesting substrate, and B. burgdorferi s.l. infection status on avian tick burden. Each avian species was categorized by preferred foraging substrate and nesting type based on prior studies $[15,41,56]$ with site included as a random effect. Models were implemented in the R package glmmTMB [57]. Model family was chosen based on the data distribution and the best models were chosen by comparing Akaike Information Criterion (AIC) scores. A two-sample t-test assuming unequal variance was also performed in excel 
to calculate the difference in tick burden between ground-dwelling birds and birds that forage and nest above ground.

Vertebrate community composition impact on avian tick burden was analyzed with a zero-inflated negative binomial GLMM with avian tick burden as the response variable and vertebrate species abundance, richness, and diversity as fixed effects. Models were again created using the R package $\operatorname{glmmTMB}$ and the model family was chosen based on the data distribution. The best models were chosen by comparing AIC scores.

To address what avian traits and host community parameters influence the probability of avian B. burgdorferi s.l. infection, binomial GLMM analyses were used with avian B. burgdorferi s.l. infection status set as a binary response variable. We constructed three separate GLMM models to address how avian B. burgdorferi s.l. infection is predicted by (1) natural history and avian demographic variables, (2) vertebrate community structure, specifically richness, and (3) pathogen prevalence in hosts and ticks. Separate models were constructed to not overparameterize the models and because host community richness and host prevalence variables were collinear. In addition, all metrics of tick infection prevalence, density of nymphs (DON), nymphal infection prevalence (NIP), and density of infected nymphs (DIN) were correlated for data collected in 2019, the year that bird data were collected, and for 2018, the previous year. Because of the life cycle of the tick, host infection prevalence for long lived species can sometimes be better predicted by lagged data, i.e., nymph infection prevalence in the previous year [58]. For all models, fixed effects for each model were checked for collinearity and site was included as a random effect. We first examined the relationship between avian infection prevalence and host life history traits in what we call model 1. This model included bird species, sex, mass, foraging and nesting substrate category, and tick burden as fixed effects. Next, we examined the role of vertebrate community composition in model 2 which included avian richness, rodent richness, and predator richness as fixed effects. Lastly, we explored the influence of reservoir host infection prevalence and the potential for a lagged effect in model 3 which included N. fuscipes infection prevalence with B. burgdorferi s.l. and the nymphal infection prevalence from both the current year (2019) and the previous year (2018). Model comparison was conducted using AIC scores to determine the most parsimonious model. Host infection analysis focused on N. fuscipes infection prevalence only because Peromyscus infection prevalence was highly correlated with $N$. fuscipes infection prevalence and because N. fuscipes is a more important contributor to local B. burgdorferi s.l. transmission [17].

\section{Results}

\subsection{Host Community Composition: Birds, Small Mammals, and Medium to Large Mammals}

Across all nine sites, 160 individual birds belonging to 23 different species were caught and processed. Statistical analysis of avian tick burden focused on 118 individual birds from six bird species that included individuals infected with B. burgdorferi s.l. and had a sample size $\geq 5$ individuals across all sites: the oak titmouse (Baeolophus inornatus), spotted towhee (Pipilo maculatus), pacific slope flycatcher (Empidonax difficilis), dark-eyed junco (Junco hyemalis), Bewick's wren (Thryomanes bewickii), and lesser goldfinch (Spinus psaltria) (Table 1). Of these six species examined, the pacific slope flycatcher is a migratory species through the western United States while the remaining five are non-migratory resident birds in the region [41]. 
Table 1. Avian host community sampling distribution, Borrelia burgdorferi s.l. infection prevalence, foraging and nesting substrate by bird species included in analysis.

\begin{tabular}{cccccc}
\hline Species & $\begin{array}{c}\text { N Tested for B. } \\
\text { burgdorferi s.l. }\end{array}$ & $\begin{array}{c}\text { N B. burgdorferi } \\
\text { s.l. Infected (\%) }\end{array}$ & $\begin{array}{c}\text { Average } \\
\text { Tick Burden }\end{array}$ & $\begin{array}{c}\text { Foraging } \\
\text { Substrate }\end{array}$ & $\begin{array}{c}\text { Nesting } \\
\text { Substrate }\end{array}$ \\
\hline Bewick's Wren & $16(11)$ & $2(18)$ & 0 & Aboveground & Aboveground \\
Ground & Ground \\
Dark-eyed Junco & $67(65)$ & $14(21.5)$ & 0.28 & Aboveground Aboveground \\
Lesser Goldfinch & $6(5)$ & $2(40)$ & 0 & Aboveground & Aboveground \\
Oak Titmouse & $11(7)$ & $1(14)$ & 0.55 & Aboveground Aboveground \\
Pacific Slope Flycatcher & $6(5)$ & $2(40)$ & 0.08 & Ground & Ground \\
Spotted Towhee & $12(8)$ & $23(25)$ & 0.22 & \\
Totals & $118(101)$ & $23)$ & & \\
\hline
\end{tabular}

Statistical analyses of avian B. burgdorferi s.l. infection focused on these same six bird species but excluded 17 individuals (101 total birds) that were checked for ticks but unable to have blood drawn.

Across all sites, five different small mammal species were caught; the dusky-footed woodrat (Neotoma fuscipes), deer mouse (Peromyscus maniculatus), California deer mouse (Peromyscus californicus), pinyon mouse (Peromyscus truei), and western harvest mouse (Reithrodontomys megalotis). Total abundance of $N$. fuscipes was estimated to be 51 individuals across all sites (Tables S1 and S2). Western fence lizards (Sceloporus occidentalis) were observed at six of the nine sites and overall abundance was estimated to be 299 individuals (Table S1). Our wildlife cameras detected six terrestrial mammal species known to prey upon small birds that were captured on our camera traps: the bobcat (Lynx rufus), gray fox (Urocyon cinereoargenteus), coyote (Canis latrans), skunk (Mephitis mephitis), raccoon (Procyon lotor), and opossum (Didelphis virginiana) [59].

\subsection{Vector Suveillance: Bird-Attached and Questing Ticks}

A total of 26 bird-attached I. pacificus ticks were removed from 13 individual birds, with 11 larvae and 15 nymphal ticks from the bird species included in analyses for an average tick burden of 0.22 ticks per bird (Table 1). Three additional Haemaphysalis ticks (Two H. leporispalustris and one H. chordeilis) were also found attached to the birds but were not included in our analyses. A total of 338 questing nymphal I. pacifus ticks were collected and tested for B. burgdorferi s.l. (Table S2).

\subsection{Pathogen Surveillance: Borrelia burgdorferi Sensu Lato Prevalence}

The overall avian B. burgdorferi s.l. infection prevalence across all sites and species was $22.8 \%$, ( $\mathrm{N}=23 / 101)$. One dark-eyed Junco (Junco hyemalis) was infected with $B$. bissettiae while 18 birds were infected with $B$. burgdorferi s.s. There were no birds coinfected with multiple Borrelia species. Four birds included in B. burgdorferi s.l. analysis tested positive for B. burgdorferi s.l. but did not yield informative sequence results. The overall B. burgdorferi s.l. infection prevalence of $N$. fuscipes was $29.5 \%$ while the overall nymphal I. pacificus tick infection prevalence was $15 \%$ across all nine sites (Table S2).

\subsection{Statistical Analysis: Probability of Avian Tick Burden}

Avian tick burden was not significantly correlated with foraging or nesting substrate $[15,60]$ (Figure S1). We did not find an association between tick burden and avianassociated demographic or morphometric traits either such as weight, sex, or species.

Of the host community characteristics examined, relative predator abundance and S. occidentalis abundance were significant predictors of intensity of avian tick burden (predator abundance estimate $=-10.55, p<0.001$; lizard abundance estimate $=0.02, p=0.05$ ) (Figure 2, Table 2). There was no significant pattern found between avian tick burden and abundance of small mammals or abundance of birds detected in our study (Table 2). Other elements of host community composition including Shannon diversity and richness 
of: predators, small mammals, birds, and lizards, were not significant predictors of avian tick burden.

\section{Predicted avian tick burden by abundance of predators and lizards}
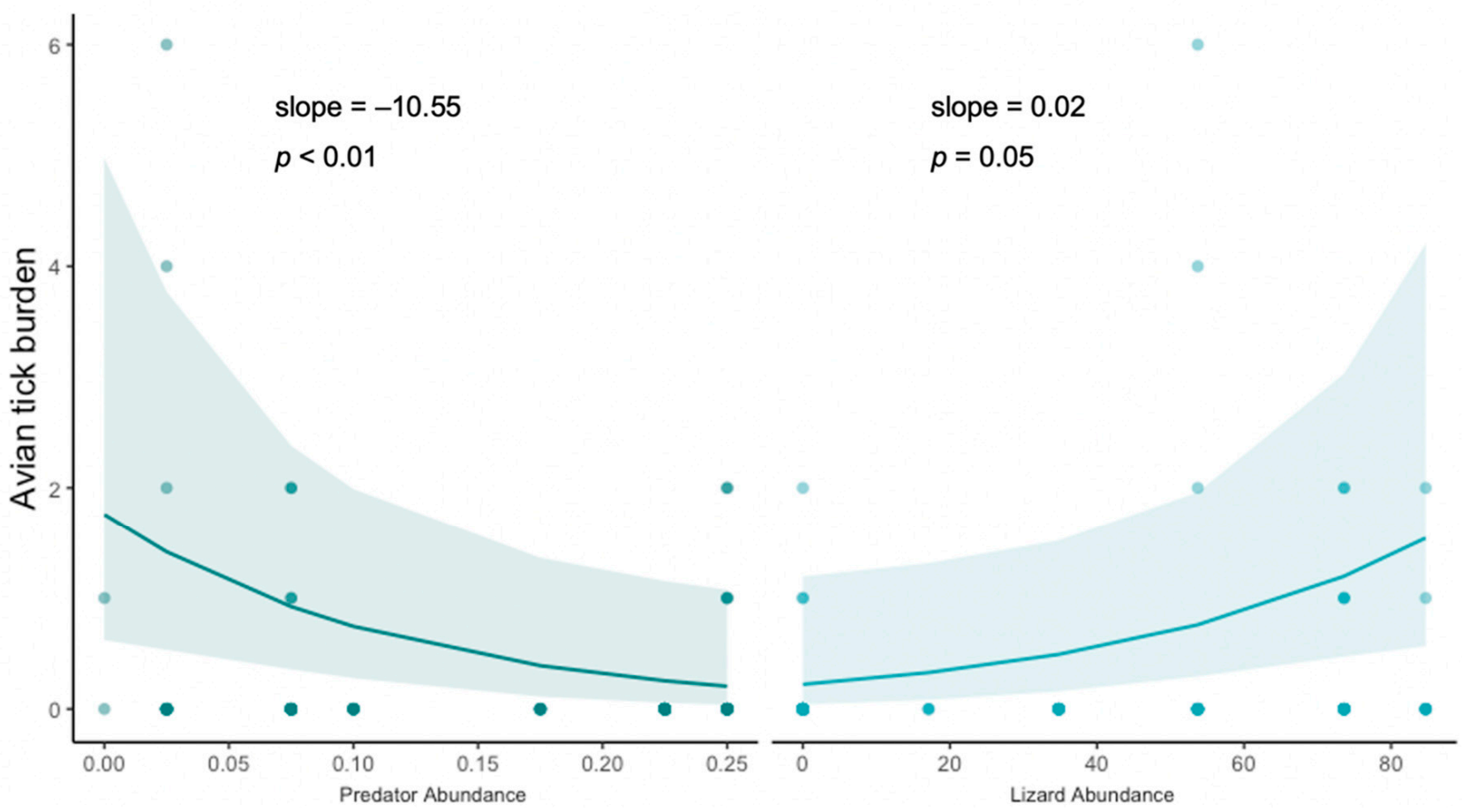

Figure 2. Zero-inflated Poisson distributed generalized linear model result of relative predator abundance and S. occidentalis lizard abundance as predictors of avian tick burden with site as a random effect. Raw data jittered over model prediction.

Table 2. Zero-inflated Poisson generalized linear model results of host community characteristics as predictors of avian tick burden with site as a random variable.

\begin{tabular}{|c|c|c|c|c|c|}
\hline $\begin{array}{l}\text { Response } \\
\text { Variable }\end{array}$ & Model Component & Estimate & $\begin{array}{l}\text { Standard } \\
\text { Error }\end{array}$ & Z-Value & $p$-Value \\
\hline \multirow[t]{5}{*}{ Avian tick burden } & (Intercept) & -0.15 & 0.99 & -0.15 & 0.88 \\
\hline & Predator abundance & -10.55 & 3.28 & -3.22 & $0.001 * *$ \\
\hline & Bird abundance & 0.04 & 0.03 & 1.11 & 0.26 \\
\hline & N. fuscipes abundance & -0.06 & 0.06 & -1.05 & 0.29 \\
\hline & $\begin{array}{l}\text { S. occidentalis } \\
\text { abundance }\end{array}$ & 0.02 & 0.01 & 0.77 & $0.05 *$ \\
\hline
\end{tabular}

* and ${ }^{* *}$ denote significance level.

The model results of GLMM analyses did not find a significant relationship between host natural history or demographic variables on the probability of avian infection with B. burgdorferi (model 1). In model 2 we found a significant and positive correlation between rodent species richness and the probability of B. burgdorferi s.l. infection in birds, but bird and predator species richness were not significant predictors (Table 3). Reservoir host infection analysis (model 3) focused on $N$. fuscipes infection prevalence as well as nymphal B. burgdorferi s.l. infection prevalence (NIP) and showed that $N$. fuscipes infection prevalence in 2019 and NIP in 2018 were the most significant and parsimonious predictors of probability of avian B. burgdorferi s.l. infection in 2019 (Figure 3, Table 3). 
Table 3. Binomial model results of natural history and host demographic variables, and host community characteristics as predictors of avian B. burgdorferi s.l. infection status with site as a random variable.

\begin{tabular}{|c|c|c|c|c|c|c|}
\hline $\begin{array}{c}\text { Model } \\
\text { Number }\end{array}$ & Response Variable & Model Component: & Estimate & $\begin{array}{c}\text { Standard } \\
\text { Error }\end{array}$ & Z-Value & $p$-Value \\
\hline \multirow[t]{14}{*}{ Model 1} & \multirow[t]{14}{*}{ Avian B. burgdorferi s.l. infection } & (Intercept) & -1.81 & 0.94 & -1.91 & 0.06 \\
\hline & & Bird species: & & & & \\
\hline & & J. hyemalis & 0.16 & 1 & 0.16 & 0.87 \\
\hline & & S. psaltria & -0.73 & 1.48 & -0.49 & 0.62 \\
\hline & & B. inornatus & -1.62 & 1.59 & -1.02 & 0.3 \\
\hline & & E. difficilis & 1.23 & 1.58 & 0.78 & 0.43 \\
\hline & & P. maculatus & 0.95 & 1.45 & 0.66 & 0.51 \\
\hline & & Sex: & & & & \\
\hline & & Male & 0.26 & 0.82 & 0.32 & 0.75 \\
\hline & & Unknown & 0.16 & 0.7 & 0.23 & 0.82 \\
\hline & & Mass & 0.01 & 0.02 & 0.36 & 0.72 \\
\hline & & $\begin{array}{l}\text { Foraging and nesting } \\
\text { substrate: }\end{array}$ & & & & \\
\hline & & Aboveground & -0.4 & 0.67 & -0.6 & 0.54 \\
\hline & & Tick burden & 0.32 & 0.59 & 0.55 & 0.58 \\
\hline \multirow[t]{4}{*}{ Model 2} & \multirow[t]{4}{*}{ Avian B. burgdorferi s.l. infection } & (Intercept) & -4.28 & 1.3 & -3.3 & $<0.001 * * *$ \\
\hline & & Avian richness & 0.009 & 0.1 & 0.1 & 0.92 \\
\hline & & Rodent richness & 1.3 & 0.33 & 3.91 & $<0.001 * * *$ \\
\hline & & Predator richness & -0.26 & 0.39 & -0.65 & 0.52 \\
\hline \multirow[t]{2}{*}{ Model 3} & \multirow[t]{2}{*}{ Avian B. burgdorferi s.l. infection } & (Intercept) & -3.25 & 0.59 & -5.47 & $<0.001 * * *$ \\
\hline & & $\begin{array}{l}\text { Nymphal infection } \\
\text { prevalence } 2018 \\
N \text {. fuscipes } B . \\
\text { burgdorferi s.1. } \\
\text { infection } \\
\text { prevalence } 2019\end{array}$ & 11.13 & 2.79 & 3.95 & $<0.001 * * *$ \\
\hline
\end{tabular}

${ }^{*}$ and ${ }^{* * *}$ denote significance level.
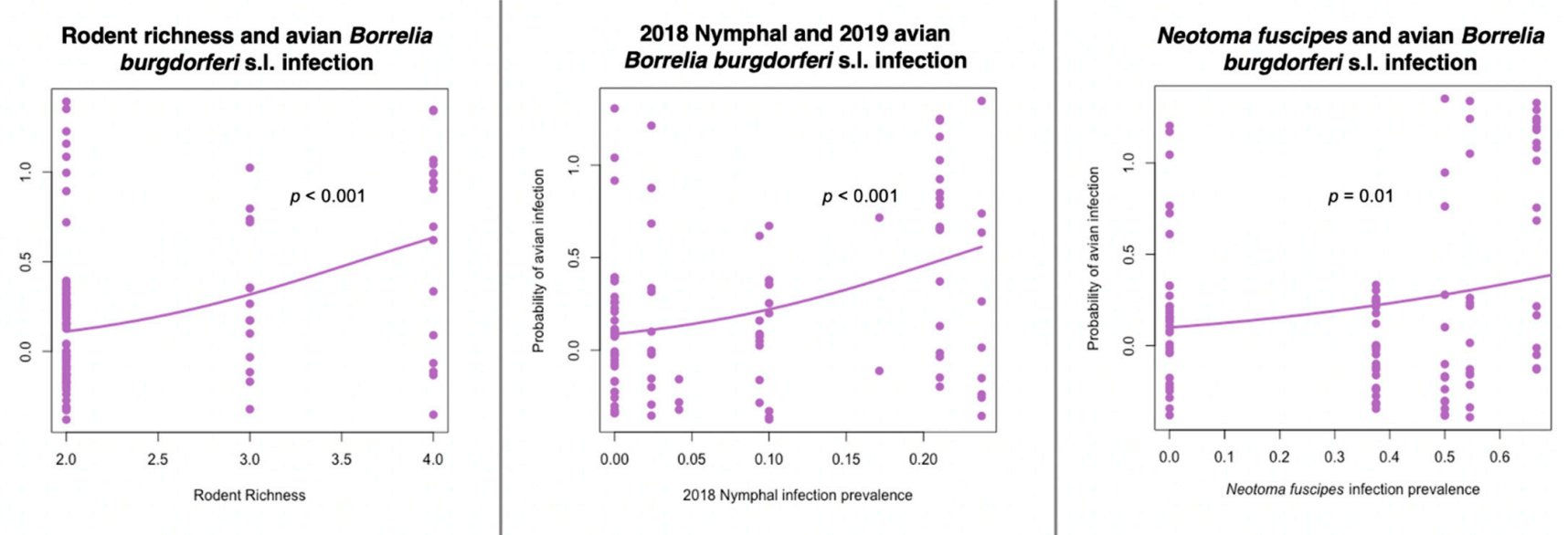

Figure 3. Rodent community composition and tick infection prevalence significantly predicts the probability of avian Borrelia burgdorferi sensu lato infection. Raw data jittered over model predictions. 


\section{Discussion}

The etiological agent of Lyme disease is maintained by a complex enzootic cycle that requires a tick vector and competent reservoir hosts to persist [6]. While many studies have focused on the role of rodents in Lyme disease transmission because of their importance and competence as reservoir hosts, birds are relatively understudied but may be important in the sylvatic cycle of Lyme disease. This study sought to determine the host and community composition traits that affect the role of birds as both tick hosts and B. burgdorferi s.l. pathogen reservoirs. Not only does our study assess the tick infestation and B. burgdorferi s.l. infection prevalence of wild birds, but we examine their role in the context of a local enzootic cycle. Our analyses found that local terrestrial predator and western fence lizard abundance are predictive of intensity of avian tick infestation. Despite the high vagility of birds, we found that avian B. burgdorferi s.l. infection was highly predicted by rodent richness and site-specific rodent and tick infection prevalence. These results show that bird infection prevalence is highly concordant with local mam-mal and tick infection, indicating that they are likely acquiring infection locally. By showing that avian tick burden and B. burgdorferi s.l. infection status is associated with elements of local community composition, our study confirms that birds, especially the resident bird species examined in this study, are potentially important hosts for maintaining local Borrelia burgdorferi sensu lato transmission dynamics in the western United States.

Tick burden is an important determinant of whether a host is a competent $B$. burgdorferi s.l. reservoir. The tick burdens of the avian species in our study had a low average (0.22) but wide range of 0-6 ticks per bird, consistent with other studies of avian tick burdens across North America $[15,60,61]$. However, due to logistical constraints, the timing of avian sampling extended three months beyond the peak nymphal and larval questing period, so our burden averages are likely an underrepresentation of avian tick burden. Contrary to previous studies, intensity of tick infestation was not significantly associated with avian morphometrics nor life history traits [15,19,36,60-62]. However, it is possible that limited sample size or our study design which only included six distinct bird species in analysis may not have provided a robust enough species sampling to uncover patterns related to species specific life history and morphometric traits.

We found that predator abundance was a significant, negative driver of avian tick burden with tick infestation decreasing as predator abundance increased. These results are consistent with recent findings that small mammal tick burdens are negatively impacted by predator composition [46]. Our results suggest that although predators can regulate tick populations by limiting host availability, this was not the case for our study system because we did not find a negative effect of predator abundance on host populations [46]. Another possible mechanism to explain this pattern is supported by the 'ecology of fear' hypothesis [63]. In the presence of a high density of predators, birds might spend less time on the ground foraging or resting where they are more likely to encounter ticks $[15,19,64-69]$. This hypothesis is supported by a large body of literature indicating that increased levels of predation cause prey to spend more time engaged in predator avoidance and vigilance behaviors and less time on the ground foraging [70-74]. By reducing their nesting density and foraging behavior in the presence of high terrestrial predator activity [49], grounddwelling birds would also reduce encounters with ticks. Behavioral observation studies would be useful to shed light on this idea.

In addition to local predator abundance, we found that western fence lizard (S. occidentalis) abundance was a positive predictor of avian tick burden. Sceloporus occidentalis are the primary I. pacificus tick host in the western United States and lizard presence has been experimentally shown to influence local tick population dynamics [19,75]. Although abundance of questing of I. pacificus nymphs alone was not a significant driver of avian tick burden, it is possible that the lizard population drives the total tick population (including both questing ticks and those already attached to available hosts) and thus lizard abundance may lead to an increase in total ticks present at each site. 
The high vagility of birds suggests that they may be important for long distance dispersal of ticks or pathogens between remote geographic locations, however our study indicates that birds are more likely acquiring infections locally based on their significant association with site-specific rodent richness, $N$. fuscipes infection prevalence, and nymphal tick infection prevalence (Table 3) $[21,31,60,62,76,77]$. This is consistent with the idea that the likelihood of a bird encountering an infected tick and becoming infected would be higher where there is greater transmission of B. burgdorferi s.l. at the community level. Neotoma fuscipes are a primary reservoir host for B. burgdorferi s.l. and thus their infection prevalence should reflect rates of overall risk of B. burgdorferi s.l. Avian B. burgdorferi s.l. infection prevalence was significantly associated with NIP of the previous year, but not NIP of the concurrent avian sampling year. This could indicate that birds, with lifespans of 2 to 11 years, may be acquiring infection in the previous season [41]. Alternatively, these results could reflect variability in detection of infection between the tick population and avian blood samples.

Overall avian infection prevalence $(22.8 \%)$ is comparable to other known reservoir host species such as $N$. fuscipes (29.5\%). Due to the limitations of detecting B. burgdorferi s.l. in blood compared to tissue [28], these infection rates may be an underestimate of avian infection prevalence. The ability of birds to serve as competent reservoirs in local transmission dynamics relies on the ability of these infected birds to transmit B. burgdorferi s.l. to a naïve feeding tick, a component of transmission that we did not measure in this study. An experimental study conducted by Richter et al. (2000) [30] found that laboratory infected American robins (Turdus migratorius) were comparable to rodents at acquiring and transmitting $B$. burgdorferi s.l. infection to ticks, suggesting that birds could be reservoir hosts for B. burgdorferi s.l., however, the experiment found that the infection status of robins waned more rapidly than that of rodents [30]. Future studies should further investigate the reservoir capacity of avian hosts through xenodiagnostic experiments of transmission efficiency of $B$. burgdorferi s.l. between birds and ticks.

While our study found relatively high rates of B. burgdorferi s.l. infection among avian hosts, we did not assess the impact of B. burgdorferi s.l. on avian fitness. Among birds, there is high interspecific variability in tolerance versus resistance to different parasites [78-81]. Although laboratory experiments artificially infecting birds with B. burgdorferi s.l. have shown no clinical symptoms of Borrelia infection nor detectable impact on avian health, the long-term impact of B. burgdorferi s.l. infection on wild avian host fitness remains to be determined $[21,28]$. The long-term avian health impact of B. burgdorferi s.l. infection could have important implications for their overall reservoir competency [30]. Birds typically have a much longer lifespan than small mammals, with the bird species we sampled living up to maximums of 7-11 years compared to 1-3 years for our rodent reservoir hosts such as Peromyscus mice and woodrats $[41,82]$. This difference in lifespan, if combined with persistent infection, could result in birds playing a more important role in pathogen maintenance over the course of their life. If one exposure event to an infected tick results in a persistent infection over the life of the bird, birds could be especially important for carrying the pathogen between years and maintaining rare B. burgdorferi s.l. genotypes in the population [25,32,83-86]. Our study found both B. burgdorferi and Borrelia bissettiae in avian hosts, confirming a finding by Newman et al. (2015) [15]. Additional studies on the persistence of other genospecies of B. burgdorferi s.l. in birds would greatly improve our understanding of the potential life-long contribution of birds to pathogen transmission and diversity.

While our study focused mostly on resident songbird communities that are not likely to move more than 15-95 km, one species included in our analyses, the pacific slope flycatchers, are part of the over 65 million land birds that migrate through California each year and could transport ticks and B. burgdorferi s.l. during their journey and underscore the importance of studying both resident and migratory birds [60,87-90]. Ogden et al. (2008) [31] found that migratory birds transport 50-175 million ticks across Canada each spring, with a B. burgdorferi s.l. infection prevalence of $15.8 \%$ in attached nymphs. While 
it is unclear if ticks are able to establish after relocation via avian hosts, there is clear potential for birds to increase existing tick populations and introduce novel genetic variants of B. burgdorferi s.1. [90]. Additionally, migratory birds often interact with resident bird populations and rely on them for finding suitable foraging and nesting sites [88,91]. The high prevalence of B. burgdorferi s.l. detected in bird species in our study could lead to an increased likelihood of pathogen spread to migratory birds through shared habitat and spread of pathogen infected attached ticks to new regions [28,31].

\section{Conclusions}

Our study examines how complex community interactions drive avian B. burgdorferi s.l. infection prevalence and tick parasitism among resident bird populations in the western United States. Many of the bird species that were examined in this study are resident species with limited dispersal behavior and our analyses indicate that these birds are likely acquiring infection locally. Our findings that rodent richness is driving avian B. burgdorferi s.l. infection status and that predator and lizard abundances are driving avian tick burden highlight the importance of considering full community dynamics when evaluating birds, or any other host, as a potential B. burgdorferi s.l. reservoir. Future studies should focus on the reservoir competency and ability of key bird species to infect ticks in order to further resolve the role of birds in local B. burgdorferi s.l. transmission dynamics and their potential for maintaining and spreading B. burgdorferi s.l. to new environments.

Supplementary Materials: The following supporting information can be downloaded at: https: / / www.mdpi.com/article/10.3390/vetsci9020055/s1, Table S1: Community richness and abundance estimates included in analyses across all sites, Table S2: Tick and reservoir host community characteristics included in analysis, Figure S1: Average avian tick burden does not differ by level of ground activity.

Author Contributions: Conceptualization, M.L., W.A.-M., L.P. and A.S.; methodology, M.L., W.A.-M., L.P., R.S. and A.S.; software, M.L., A.S. and C.P.; validation, M.L., A.S., W.A.-M. and L.P.; formal analysis, M.L. and A.S.; investigation, M.L., A.S., W.A.-M., L.P., C.P., A.C., N.T. and R.S.; resources, A.S., W.A.-M., L.P. and R.S.; data curation, M.L., A.S., W.A.-M., L.P., C.P., A.C., N.T. and R.S.; writingoriginal draft preparation, M.L. and A.S.; writing-review and editing, M.L., A.S., W.A.-M., L.P., C.P., A.C. and R.S.; supervision, A.S. and R.S.; project administration, A.S., W.A.-M., L.P., C.P., A.C. and R.S.; funding acquisition, M.L., W.A.-M., L.P. and A.S. All authors have read and agreed to the published version of the manuscript.

Funding: This research was funded by the National Science Foundation grant number 175037 and 1745411; and National Science Foundation Graduate Research Fellowship under grant number 10328000.

Institutional Review Board Statement: The study was conducted according to the guidelines of the Declaration of Helsinki, and approved by the Institutional Review Board of San Francisco State University IACUC protocol code AU19-01R2 and by the Institutional Review Board of Stanford University IACUC protocol code 337733.

Informed Consent Statement: Not applicable.

Data Availability Statement: The data presented in this study are openly available in GenBank (GenBank MZ852103-MZ852212) or contained within the article.

Acknowledgments: We acknowledge Jordan Salomon, Samantha Sambado, Kacie Ring, Aoife Galvin, Monika Koczela-Stillman, Laura Hughes, and Adrienne Almarinez for their help with sample collection and processing. We would like to thank Edward Connor for his review of the initial draft and to thank Grace Shaw for creating Figure 1. This research was conducted on Native lands of: Ramaytush, Ohlone, Chochenya and Wappo. We thank the City of Belmont, California State Parks, East Bay Municipal Water District, Marin Open Space Trust, San Mateo County Parks, Sonoma Regional Parks, Midpeninsula Regional Open Space and the Town of Los Gatos for access to conduct research in their parks.

Conflicts of Interest: The authors declare no conflict of interest. 


\section{References}

1. Kilpatrick, A.M.; Randolph, S.E. Drivers, dynamics, and control of emerging vector-borne zoonotic diseases. Lancet 2012, 380, 1946-1955. [CrossRef]

2. Rosenberg, R.; Lindsey, N.P.; Fischer, M.; Gregory, C.J.; Hinckley, A.F.; Mead, P.S.; Paz-Bailey, G.; Waterman, S.H.; Drexler, N.A.; Kersh, G.J.; et al. Vital signs: Trends in reported vectorborne disease cases-United States and Territories, 2004-2016. Morb. Mortal. Wkly. Rep. 2018, 67, 496. [CrossRef]

3. Khodayari-Zarnaq, R.; Alizadeh, G.; Alizadeh, G. Emerging and Re-emerging Diseases: Policies and Strategies for Future. Evid. Based Health Policy Manag. Econ. 2020, 4, 154-158. [CrossRef]

4. Madison-Antenucci, S.; Kramer, L.D.; Gebhardt, L.L.; Kauffman, E. Emerging Tick-Borne Diseases. Clin. Microbiol. Rev. 2020, 33, e00083-18. [CrossRef]

5. CDC. Reported Cases of Lyme Disease-United States, 2018. 2018. Available online: https://www.cdc.gov/lyme/ datasurveillance/maps-recent.html (accessed on 29 April 2021)

6. Johnson, R.C.; Schmid, G.P.; Hyde, F.W.; Steigerwalt, A.G.; Brenner, D.J. Borrelia burgdorferi sp. nov.: Etiologic agent of Lyme disease. Int. J. Syst. Evol. Microbiol. 1984, 34, 496-497. [CrossRef]

7. Burgdorfer, W.; Barbour, A.G.; Hayes, S.F.; Benach, J.L.; Grunwaldt, E.; Davis, J.P. Lyme disease-a tick-borne spirochetosis? Science 1982, 216, 1317-1319. [CrossRef]

8. $\quad$ Burgdorfer, W.; Lane, R.S.; Barbour, A.G.; Gresbrink, R.A.; Anderson, J.R. The western black-legged tick, Ixodes pacificus: A vector of Borrelia burgdorferi. Am. J. Trop. Med. Hyg. 1985, 34, 925-930. [CrossRef]

9. Rudenko, N.; Golovchenko, M.; Grubhoffer, L.; Oliver, J.H. Updates on Borrelia Burgdorferi Sensu Lato Complex with Respect to Public Health. Ticks Tick-Borne Dis. 2011, 2, 123-128. [CrossRef]

10. Leydet, B.F.; Liang, F.T. Unexpected Failure of Ixodes Scapularis Nymphs to Transmit a North American Borrelia Bissettiae Strain Curr. Res. Parasitol. Vector-Borne Dis. 2021, 1, 100039. [CrossRef]

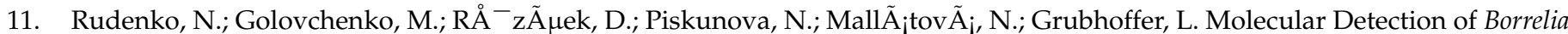
bissettii DNA in Serum Samples from Patients in the Czech Republic with Suspected Borreliosis. FEMS Microbiol. Lett. 2009, 292, 274-281. [CrossRef]

12. Girard, Y.A.; Fedorova, N.; Lane, R.S. Genetic Diversity of Borrelia Burgdorferi and Detection of B. bissettii-Like DNA in Serum of North-Coastal California Residents. J. Clin. Microbiol. 2011, 49, 945-954. [CrossRef]

13. Castro, M.B.; Wright, S.A. Vertebrate Hosts of Ixodes Pacificus (Acari: Ixodidae) in California. J. Vector Ecol. 2007, 32, 140-149. [CrossRef]

14. Lane, R.S.; Mun, J.; Eisen, R.J.; Eisen, L. Western Gray Squirrel (Rodentia: Sciuridae): A Primary Reservoir Host of Borrelia Burgdorferi in Californian Oak Woodlands? J. Med. Entomol. 2005, 42, 9. [CrossRef]

15. Newman, E.A.; Eisen, L.; Eisen, R.J.; Fedorova, N.; Hasty, J.M.; Vaughn, C.; Lane, R.S. Borrelia Burgdorferi Sensu Lato Spirochetes in Wild Birds in Northwestern California: Associations with Ecological Factors, Bird Behavior and Tick Infestation. PLoS ONE 2015, 10, e0118146. [CrossRef]

16. Donahue, J.G.; Piesman, J.; Spielman, A. Reservoir Competence of White-Footed Mice for Lyme Disease Spirochetes. Am. J. Trop. Med. Hyg. 1987, 36, 92-96. [CrossRef]

17. Swei, A.; Briggs, C.J.; Lane, R.S.; Ostfeld, R.S. Impacts of an Introduced Forest Pathogen on the Risk of Lyme Disease in California Vector-Borne Zoonotic Dis. 2012, 12, 623-632. [CrossRef]

18. Brown, R.N.; Lane, R.S. Reservoir Competence of Four Chaparral-Dwelling Rodents for Borrelia Burgdorferi in California. Am. J. Trop. Med. Hyg. 1996, 54, 84-91. [CrossRef]

19. Eisen, L.; Eisen, R.J.; Lane, R.S. The roles of birds, lizards, and rodents as hosts for the western black-legged tick Ixodes pacificus J. Vector Ecol. J. Soc. Vector Ecol. 2004, 29, 295-308.

20. Salkeld, D.J.; Leonhard, S.; Girard, Y.A.; Hahn, N.; Mun, J.; Padgett, K.A.; Lane, R.S. Identifying the reservoir hosts of the Lyme disease spirochete Borrelia burgdorferi in California: The role of the western gray squirrel (Sciurus griseus). Am. J. Trop. Med. Hyg. 2008, 79, 535-540. [CrossRef]

21. Anderson, J.F.; Magnarelli, L.A. Avian and Mammalian Hosts for Spirochete-Infected Ticks and Insects in a Lyme Disease Focus in Connecticut. Yale J. Biol. Med. 1984, 57, 627-641.

22. Brinkerhoff, R.J.; Folsom-O'Keefe, C.M.; Tsao, K.; Diuk-Wasser, M.A. Do Birds Affect Lyme Disease Risk? Range Expansion of the Vector-borne Pathogen Borrelia Burgdorferi. Front. Ecol. Environ. 2011, 9, 103-110. [CrossRef]

23. Olsen, B.; Gylfe, Å.; Bergström, S. Canary Finches (Serinus canaria) as an Avian Infection Model for Lyme Borreliosis. Microb. Pathog. 1996, 20, 319-324. [CrossRef]

24. Ginsberg, H.S.; Buckley, P.A.; Balmforth, M.G.; Zhioua, E.; Mitra, S.; Buckley, F.G. Reservoir Competence of Native North American Birds for the Lyme Disease Spirochete, Borrelia Burgdorferi. J. Med. Entomol. 2005, 42, 5. [CrossRef]

25. Vuong, H.B.; Canham, C.D.; Fonseca, D.M.; Brisson, D.; Morin, P.J.; Smouse, P.E.; Ostfeld, R.S. Occurrence and Transmission Efficiencies of Borrelia Burgdorferi OspC Types in Avian and Mammalian Wildlife. Infect. Genet. Evol. 2014, 27, 594-600. [CrossRef]

26. Heylen, D.J.A. Ecological interactions between songbirds, ticks, and Borrelia burgdorferi s.l. in Europe. In Ecology and Control of Vector-Borne Diseases; Braks, M.A.H., van Wieren, S.E., Takken, W., Sprong, H., Eds.; Wageningen Academic Publishers: Wageningen, The Netherlands, 2016; Volume 4, pp. 91-101. ISBN 978-90-8686-293-1. 
27. Humair, P.-F.; Postic, D.; Wallich, R.; Gern, L. An Avian Reservoir (Turdus merula) of the Lyme Borreliosis Spirochetes. Zent. Für Bakteriol. 1998, 287, 521-538. [CrossRef]

28. Norte, A.C.; Lopes de Carvalho, I.; Núncio, M.S.; Araújo, P.M.; Matthysen, E.; Albino Ramos, J.; Sprong, H.; Heylen, D. Getting under the Birds' Skin: Tissue Tropism of Borrelia burgdorferi s.l. in Naturally and Experimentally Infected Avian Hosts. Microb. Ecol. 2020, 79, 756-769. [CrossRef]

29. Comstedt, P.; Bergström, S.; Olsen, B.; Garpmo, U.; Marjavaara, L.; Mejlon, H.; Barbour, A.G.; Bunikis, J. Migratory Passerine Birds as Reservoirs of Lyme Borreliosis in Europe. Emerg. Infect. Dis. 2006, 12, 1087-1095. [CrossRef]

30. Richter, D.; Spielman, A.; Komar, N.; Matuschka, F. Competence of American Robins as Reservoir Hosts for Lyme Disease Spirochetes. Emerg. Infect. Dis. 2000, 6, 133-138. [CrossRef] [PubMed]

31. Ogden, N.H.; Lindsay, L.R.; Hanincová, K.; Barker, I.K.; Bigras-Poulin, M.; Charron, D.F.; Heagy, A.; Francis, C.M.; O’Callaghan C.J.; Schwartz, I.; et al. Role of Migratory Birds in Introduction and Range Expansion of Ixodes Scapularis Ticks and of Borrelia Burgdorferi and Anaplasma Phagocytophilum in Canada. Appl. Environ. Microbiol. 2008, 74, 1780-1790. [CrossRef] [PubMed]

32. Patrican, L.A. Absence of Lyme Disease Spirochetes in Larval Progeny of Naturally Infected Ixodes Scapularis (Acari: Ixodidae) Fed on Dogs. J. Med. Entomol. 1997, 34, 52-55. [CrossRef] [PubMed]

33. LoGiudice, K.; Ostfeld, R.S.; Schmidt, K.A.; Keesing, F. The Ecology of Infectious Disease: Effects of Host Diversity and Community Composition on Lyme Disease Risk. Proc. Natl. Acad. Sci. USA 2003, 100, 567-571. [CrossRef]

34. Diuk-Wasser, M.A.; Hoen, A.G.; Cislo, P.; Brinkerhoff, R.; Hamer, S.A.; Rowland, M.; Cortinas, R.; Vourćh, G.; Melton, F.; Hickling, G.J.; et al. Human Risk of Infection with Borrelia burgdorferi, the Lyme Disease Agent, in Eastern United States. Am. J. Trop. Med. Hyg. 2012, 86, 320-327. [CrossRef]

35. Falco, R.C.; McKenna, D.F.; Daniels, T.J.; Nadelman, R.B.; Nowakowski, J.; Fish, D.; Wormser, G.P. Temporal Relation between Ixodes Scapularis Abundance and Risk for Lyme Disease Associated with Erythema Migrans. Am. J. Epidemiol. 1999, 149, 771-776. [CrossRef]

36. Norte, A.C.; de Carvalho, I.L.; Ramos, J.A.; Gonçalves, M.; Gern, L.; Núncio, M.S. Diversity and Seasonal Patterns of Ticks Parasitizing Wild Birds in Western Portugal. Exp. Appl. Acarol. 2012, 58, 327-339. [CrossRef]

37. Ogrzewalska, M.; Uezu, A.; Jenkins, C.N.; Labruna, M.B. Effect of Forest Fragmentation on Tick Infestations of Birds and Tick Infection Rates by Rickettsia in the Atlantic Forest of Brazil. EcoHealth 2011, 8, 320-331. [CrossRef]

38. Lawrence, A.; O'Connor, K.; Haroutounian, V.; Swei, A. Patterns of Diversity along a Habitat Size Gradient in a Biodiversity Hotspot. Ecosphere 2018, 9, e02183. [CrossRef]

39. Padgett, K.A.; Lane, R.S. Life Cycle of Ixodes Pacificus (Acari: Ixodidae): Timing of Developmental Processes under Field and Laboratory Conditions. J. Med. Entomol. 2001, 38, 684-693. [CrossRef]

40. Dunn, E.H.; Ralph, C.J. The use of mist nets as a tool for bird population monitoring. Stud. Avian Biol. 2004, 29, 1-6.

41. Sibley, D. The North American Bird Guide; A. \& C. Black: Cambridge UK, 2000.

42. Pyle, P.; Howell, S.; Yunick, R.; Desante, D. Identification Guide to North American Birds; Slate Creek Press: Point Reyes Station, CA, USA, 1997.

43. Sehgal, R.N.M.; Jones, H.I.; Smith, T.B. Host Specificity and Incidence of Trypanosoma in Some African Rainforest Birds: A Molecular Approach. Mol. Ecol. 2001, 10, 2319-2327. [CrossRef]

44. Tchoumbou, M.A.; Mayi, M.P.A.; Malange, E.N.F.; Foncha, F.D.; Kowo, C.; Fru-cho, J.; Tchuinkam, T.; Awah-Ndukum, J.; Dorazio, R.; Nota Anong, D.; et al. Effect of Deforestation on Prevalence of Avian Haemosporidian Parasites and Mosquito Abundance in a Tropical Rainforest of Cameroon. Int. J. Parasitol. 2020, 50, 63-73. [CrossRef]

45. Marsden, J.E.; May, B. Feather Pulp: A Non-Destructive Sampling Technique for Electrophoretic Studies of Birds. Auk 1984, 101, 173-175. [CrossRef]

46. Salomon, J.; Lawrence, A.; Crews, A.; Sambado, S.; Swei, A. Host Infection and Community Composition Predict Vector Burden. Oecologia 2021, 196, 305-316. [CrossRef] [PubMed]

47. Swei, A.; Ostfeld, R.S.; Lane, R.S.; Briggs, C.J. Impact of the Experimental Removal of Lizards on Lyme Disease Risk. Proc. R. Soc. B 2011, 278, 2970-2978. [CrossRef]

48. Arizaga, J.; Deán, J.I.; Vilches, A.; Alonso, D.; Mendiburu, A. Monitoring Communities of Small Birds: A Comparison between Mist-Netting and Counting. Bird Study 2011, 58, 291-301. [CrossRef]

49. Baillargeon, S.; Rivest, L.-P. The Rcapture package: Loglinear models for capture-recapture in R. J. Stat. Softw. 2007, 19, 1-31. [CrossRef]

50. Oksanen, J.; Blanchet, F.G.; Friendly, M.; Kindt, R.; Legendre, P.; McGlinn, D.; Minchin, P.R.; O’Hara, R.B.; Simpson, G.L.; Solymos, P.; et al. Vegan: Community Ecology Package, R package version 2.5-6; CRAN, 2019; Available online: https://CRAN.R-project.org/ package $=$ vegan (accessed on 24 January 2022).

51. Fracasso, G.; Matthysen, E.; Dhondt, A.A.; Heylen, D. Experimental Study of Micro-Habitat Selection by Ixodid Ticks Feeding on Avian Hosts. Int. J. Parasitol. 2019, 49, 1005-1014. [CrossRef]

52. Furman, D.P.; Loomis, E.C. The ticks of California (Acari: Ixodida). Bull. Calif. Insect Surv. 1984, 25, 1-239.

53. Kleinjan, J.E.; Lane, R.S. Larval Keys to the Genera of Ixodidae (Acari) and Species of Ixodes (Latreille) Ticks Established in California. Pan-Pac. Entomol. 2008, 84, 121-142. [CrossRef]

54. Salomon, J.; Hamer, S.A.; Swei, A. A Beginner's Guide to Collecting Questing Hard Ticks (Acari: Ixodidae): A Standardized Tick Dragging Protocol. J. Insect Sci. 2020, 20, 11. [CrossRef] 
55. Lane, R.S.; Steinlein, D.B.; Mun, J. Human Behaviors Elevating Exposure to Ixodes Pacificus (Acari: Ixodidae) Nymphs and Their Associated Bacterial Zoonotic Agents in a Hardwood Forest. J. Med. Entomol. 2004, 41, 239-248. [CrossRef]

56. González-Salazar, C.; Martínez-Meyer, E.; López-Santiago, G. A Hierarchical Classification of Trophic Guilds for North American Birds and Mammals. Rev. Mex. De Biodivers. 2014, 85, 931-941. [CrossRef]

57. Brooks, M.E.; Kristensen, K.; van Benthem, K.J.; Magnusson, A.; Berg, C.W.; Nielsen, A.; Skaug, H.J.; Maechler, M.; Bolker, B.M. glmmTMB Balances Speed and Flexibility among Packages for Zero-inflated Generalized Linear Mixed Modeling. R J. 2017, 9, 378-400. [CrossRef]

58. Ogden, N.H.; Lindsay, L.R.; Leighton, P.A. Predicting the Rate of Invasion of the Agent of Lyme Disease Borrelia burgdorferi. J. Appl. Ecol. 2013, 50, 510-518. [CrossRef]

59. California Department of Fish and Wildlife. Life History and Range; California Department of Fish and Wildlife: Sacramento, CA, USA, 2021. Available online: https: / / wildlife.ca.gov / (accessed on 10 October 2021).

60. Loss, S.R.; Noden, B.H.; Hamer, G.L.; Hamer, S.A. A Quantitative Synthesis of the Role of Birds in Carrying Ticks and Tick-Borne Pathogens in North America. Oecologia 2016, 182, 947-959. [CrossRef]

61. Cumbie, A.N.; Heller, E.L.; Bement, Z.J.; Phan, A.; Walters, E.L.; Hynes, W.L.; Gaff, H.D. Passerine Birds as Hosts for Ixodes Ticks Infected with Borrelia Burgdorferi Sensu Stricto in Southeastern Virginia. Ticks Tick-Borne Dis. 2021, 12, 101650. [CrossRef]

62. Brinkerhoff, R.J.; Dang, L.; Streby, H.M.; Gimpel, M. Life History Characteristics of Birds Influence Patterns of Tick Parasitism. Infect. Ecol. Epidemiol. 2019, 9, 1547096. [CrossRef]

63. Brown, J.S.; Laundré, J.W.; Gurung, M. The Ecology of Fear: Optimal Foraging, Game Theory, and Trophic Interactions. J. Mammal. 1999, 80, 385-399. [CrossRef]

64. Becker, D.J.; Han, B.A. The Macroecology and Evolution of Avian Competence for Borrelia burgdorferi. bioRxiv 2021, 30, 710-724 [CrossRef]

65. Diuk-Wasser, M.A.; Gatewood, A.G.; Cortinas, M.R.; Yaremych-Hamer, S.; Tsao, J.; Kitron, U.; Hickling, G.; Brownstein, J.S.; Walker, E.; Piesman, J.; et al. Spatiotemporal Patterns of Host-Seeking Ixodes Scapularis Nymphs (Acari: Ixodidae) in the United States. J. Med. Entomol. 2006, 43, 166-176. [CrossRef]

66. Arsnoe, I.; Tsao, J.I.; Hickling, G.J. Nymphal Ixodes scapularis Questing Behavior Explains Geographic Variation in Lyme Borreliosis Risk in the Eastern United States. Ticks Tick-Borne Dis. 2019, 10, 553-563. [CrossRef]

67. Dubie, T.R.; Turner, J.; Noden, B.H. Questing Behavior and Analysis of Tick-Borne Bacteria in Ixodes Scapularis (Acari: Ixodidae) in Oklahoma. J. Med. Entomol. 2018, 55, 1569-1574. [CrossRef] [PubMed]

68. Tomkins, J.L.; Aungier, J.; Hazel, W.; Gilbert, L. Towards an Evolutionary Understanding of Questing Behaviour in the Tick Ixodes Ricinus. PLoS ONE 2014, 9, e110028. [CrossRef]

69. Bland, J.D.; Temple, S.A. Effects of Predation-Risk on Habitat Use by Himalayan Snowcocks. Oecologia 1990, 82, 187-191. [CrossRef] [PubMed]

70. Caro, T. Antipredator Defenses in Birds and Mammals; University of Chicago Press: Chicago, IL, USA, 2005.

71. Blumstein, D.T.; Bitton, A.; Da Veiga, J. How Does the Presence of Predators Influence the Persistence of Antipredator Behavior? J. Biol. 2006, 239, 460-468. [CrossRef] [PubMed]

72. Orrock, J.L.; Danielson, B.J.; Brinkerhoff, R.J. Rodent Foraging Is Affected by Indirect, but Not by Direct, Cues of Predation Risk Behav. Ecol. 2004, 15, 433-437. [CrossRef]

73. Lilly, M.V.; Lucore, E.C.; Tarvin, K.A. Eavesdropping Grey Squirrels Infer Safety from Bird Chatter. PLoS ONE 2019, 14, e0221279. [CrossRef]

74. Clermont, J.; Grenier-Potvin, A.; Duchesne, É.; Couchoux, C.; Dulude-de Broin, F.; Beardsell, A.; Bêty, J.; Berteaux, D. The Predator Activity Landscape Predicts the Anti-predator Behavior and Distribution of Prey in a Tundra Community. Ecosphere 2021, 12. [CrossRef]

75. Reed, K.D.; Meece, J.K.; Henkel, J.S.; Shukla, S.K. Birds, Migration and Emerging Zoonoses: West Nile Virus, Lyme Disease, Influenza A and Enteropathogens. Clin. Med. Res. 2003, 1, 5-12. [CrossRef]

76. Sellers, J. Tick Infestations and Their Consequences for Migratory Songbirds during Spring Stopover. Master's Thesis, University of Southern Mississippi, Hattiesburg, MS, USA, December 2011.

77. Sorci, G. Immunity, Resistance and Tolerance in Bird-Parasite Interactions. Parasite Immunol. 2013, 35, 350-361. [CrossRef]

78. Staley, M.; Bonneaud, C. Immune Responses of Wild Birds to Emerging Infectious Diseases. Parasite Immunol. 2015, 37, $242-254$. [CrossRef]

79. Burgan, S.C.; Gervasi, S.S.; Martin, L.B. Parasite Tolerance and Host Competence in Avian Host Defense to West Nile Virus. EcoHealth 2018, 15, 360-371. [CrossRef]

80. Oakgrove, K.S.; Harrigan, R.J.; Loiseau, C.; Guers, S.; Seppi, B.; Sehgal, R.N.M. Distribution, Diversity and Drivers of Blood-Borne Parasite Co-Infections in Alaskan Bird Populations. Int. J. Parasitol. 2014, 44, 717-727. [CrossRef] [PubMed]

81. Sakai, H.F.; Noon, B.R. Between-Habitat Movement of Dusky-Footed Woodrats and Vulnerability to Predation. J. Wildl. Manag. 1997, 61, 343-350. [CrossRef]

82. Gylfe, A.; Bergström, S.; Lundström, J.; Olsen, B. Reactivation of Borrelia Infection in Birds. Nature 2000, 403, 724-725. [CrossRef]

83. Brisson, D.; Dykhuizen, D.E. OspC Diversity in Borrelia Burgdorferi. Genetics 2004, 168, 713-722. [CrossRef] [PubMed] 
84. Kurtenbach, K.; Peacey, M.; Rijpkema, S.G.T.; Hoodless, A.N.; Nuttall, P.A.; Randolph, S.E. Differential Transmission of the Genospecies of Borrelia Burgdorferi Sensu Lato by Game Birds and Small Rodents in England. Appl. Environ. Microbiol. 1998, 64, 1169-1174. [CrossRef]

85. Hamer, S.A.; Hickling, G.J.; Sidge, J.L.; Rosen, M.E.; Walker, E.D.; Tsao, J.I. Diverse Borrelia Burgdorferi Strains in a Bird-Tick Cryptic Cycle. Appl. Environ. Microbiol. 2011, 77, 1999-2007. [CrossRef]

86. Tittler, R.; Villard, M.-A.; Fahrig, L. How Far Do Songbirds Disperse? Ecography 2009, 32, 1051-1061. [CrossRef]

87. Gottfried, B.M.; Franks, E.C. Habitat Use and Flock Activity of Dark-Eyed Juncos in Winter. Wilson Bull. 1975, 87, $374-383$.

88. DeLuca, W.V.; Meehan, T.; Seavy, N.; Jones, A.; Pitt, J.; Deppe, J.L.; Wilsey, C.B. The Colorado River Delta and California's Central Valley Are Critical Regions for Many Migrating North American Landbirds. Ornithol. Appl. 2021, 123, duaa064. [CrossRef]

89. Reichard, D.G.; Ketterson, E.D. Estimation of Female Home-Range Size during the Nestling Period of Dark-Eyed Juncos. Wilson J. Ornithol. 2012, 124, 614-620. [CrossRef]

90. Hasle, G. Transport of Ixodid Ticks and Tick-Borne Pathogens by Migratory Birds. Front. Cell. Infect. Microbiol. $2013,3,48$. [CrossRef] [PubMed]

91. Thomson, R.L.; Forsman, J.T.; Mönkkönen, M. Positive Interactions between Migrant and Resident Birds: Testing the Heterospecific Attraction Hypothesis. Oecologia 2003, 134, 431-438. [CrossRef] [PubMed] 